\title{
CONTEMPORARY VIETNAMESE FICTION WRITTEN ABOUT THE WAR FROM THE GENDER PERSPECTIVE
}

\author{
Thai Phan Vang Anh
}

Hue University Vietnam

\begin{abstract}
The nature of every war is the same, whether in Asian countries, in Vietnam or anywhere else. However, in reality and literature, war always brings many faces, depending on which aspects and which perspectives it is seen and explained. From the gender perspective, we believe that under a certain aspect "a war has a female face". Contemporary Vietnamese fiction describes war from the view of "feminine disposition", realizes women's beauty during and after war and condemns the brutal destruction of war from the fate of women. From the feminist perspective on war, contemporary Vietnamese fiction also mentions the instinctive desire, the desire to be loved, to be a wife, a mother of women; as well as condemns sexual prejudices to women.
\end{abstract}

Keywords: Contemporary Vietnamese fiction; War; gender perspective; The humanity view on the war; Feminist perspective.

Abstrak: Karakteristik sebuah perang dimana saja selalu sama, apakah itu di negaranegara Asia, Vietnam atau dimana saja. Secara realitas dan tulisan, perang selalu membawa beberapa sisi, tergantung dari aspek dan perspektif sisi yang dilihat dan dijelaskan, Dari perspektif gender, sebuah perang mempunyai wajah perempuan dengan aspek-aspek tertentu. Karya fiksi yang terbit di Vietnam mendeskripsikan perang dari sisi fitrah dan kodrat wanita, yang menunjukkan kecantikan wanita sebelum dan sesudah perang dan mengutuk kehancuran perang dari sisi nasib wanita Dari perspective wanita tentang perang, karya kontemporer di Vietnam menyebutkan hasrat dan insting untuk dipenuhi, seperti hasrat untuk dicintai, menjadi istri dan seorang ibu sama halnya dengan menunjukkan ketidakadilan terhadap wanita..

Kata-kata kunci: fiksi kontemporer Vietnam, perang, perspektif jender, pandangan kemanusiaan atas perang, perspektif feminis

War is always a controversial topic with no exception for any nation. In the world literary, there are many writings carrying significant meaning to all humanity. Many writings are about the glory of resounding victory and also the pain and loss of many fates during and after war. In Vietnam, the struggle against foreign aggression has been over since the late twentieth century, but the war still obsesses many post-war writers and motivates them to 
write and reappear a time of fire and sword. In reality and literature, war always brings many faces, depending on which aspects it is described and explained. There have been literary works and articles in Vietnam and the world written about the war in Vietnam. This paper aims to study Vietnamese fiction written about war after 1975 and from the gender perspective, identify the "hidden" parts of war that are rarely mentioned. From the gender perspective, we believe that $a$ war has a female face in contemporary Vietnamese fiction.

The article has chosen to study novels and short stories about war of Vietnamese writers who already fought or witnessed the devastation of the war either in the battlefield or home front (writings by Bao Ninh, Chu Lai, Nguyen Binh Phuong, Ho Anh Thai, Ta Duy Anh, Pham Ngoc Tien, Suong Nguyet Minh, Vo Thi Hao, Da Ngan, Duong Huong, Nguyen Quang Thieu, Nguyen Quang Lap). The fate of women and their views on the war in contemporary Vietnamese fiction will be given priority to make clear in the article.

The article mainly gives analysis from a gender perspective. Gender awareness is the knowledge and understanding of the differences in roles and relations between women and men. Gender awareness is severally mentioned in the aspect of sociology from the effort to achieve gender equality, protect women from social prejudices and traditional views of women underestimation and women's inferiority to men. Of course, women have their own gender - feminine that distinguishes from masculine. However, the concept of "feminine" has been stuck to women to indicate social characteristics (instead of sex and instinct) and then comes the views of women's inferiority and dependence as a result of patriarchy lasted for centuries. By considering men as the centre, women have been turned into... women as the quote of Simone de Beauvoir "One is not born, but rather becomes, a woman" (Beauvoir, 2010).

In Vietnam, there have been researches on the literature written about wars. The article of Ngo Thi Quynh Nga mentioned A new concept of reality of war in Vietnamese novels after 1975 in Vietnamese novels after 1975 (Ngo, 2016). The article of Nguyen Thi Kim Tien paid much attention to Human-being in post-war novels written about the war (Nguyen, 2010). Nguyen Huong Giang aimed to study Peace soldiers in war novels in the renovation era (Nguyen, 2001). Many discussions about literature and war have been also held... However, there has been no discussion that explains the fate of people in the war from the gender perspective while this is an interesting orientation for research on the literature written about wars. From the gender perspective, we believe that contemporary Vietnamese fiction about war has a humanity view by paying attention to the beauty of Asian women. Many writings also sees war from feminist perspective, discovers hidden parts of Vietnam through the fate of women drawn into the war.

\section{METHOD}

This method helps researcher cover contemporary fictions written about the war, based on the expression related to the gender perspective. Actually, there are many works written about the war in Vietnamese literature. This is related to the history and the tradition in againsting foreign invaders in Vietnam. And the works in the different literary periods still have similarities when writing about war, about the human conditions. In the type of war literature in Vietnam, this paper is not only showing the features of fictions written about the war but also emphasizing the relationship between war and women.

This method is used to point out the contributions, innovations of the contemporary fiction written about the war (after 1986), when compared to Vietnamese Literature on War 
in the Previous Period. Before 1986, the fictions written about the war usually mentioned the victory, the group and were rarely interested in the death, the individuals. The main characters in those works are often the hero soldiers, but rarely are the hinterland women, who are not directly with guns, though sometimes also suffered the loss more than the fighting soldiers In comparison with the previous period of Vienamese Literature, the paper shows the new points about the war in the comtemparory literature, from the women perpecstives

Based on the point system revolving the women perspectives, the paper reconstructs the appearance of the anti-American war in Vietnamese literature, which brought women face.This is an important method that specify basic characteristics of the literature written about the war when it was respected from the gender perspective and focused on themes, female character icons and feminist voices. This method is used to clarify the face of contemporary Vietnamese fictions, especially the fiction on war.

\section{FINDINGS AND DISCUSSION}

\section{The Humanity View on the War}

Many generations of women from the past to present have been struggling silently for the rights of women. Nevertheless, not until the seventeenth century, particularly in the eighteenth century, the voices of women, for women could be strongly raised. First published book entitled A Serious Proposal to the Ladies (1694) and many other books about women after that, Mary Astell has been considered as one of the first women who mentioned women's rights in her works. However, until the eighteenth century, there came true feminists. With the book A Vindication of the Rights of Woman (1792) and many literature works, the British philosopher and writer, Wollstonecraft (2009) struggled "for my gender, not myself" and was called "the first feminist", "the founding mother of feminism" (Todd, 2000). In the same period with Wollstonecraft (2009), Olympe de Gouges also provided "Declaration of the Rights of Woman and the Female Citizen" in France in 1791 and struggled for women (and for the black) until death (Naish, 1991). She declared that "Women have the right to mount the scaffold; they must also have the right to mount the speaker's rostrum" (p.137). Being considered as the first feminist in America, Judith Sargent Murray also raised the voice to strive for the equality between men and women with the essay $O n$ the Equality of the Sexes (1970) that opened up new thoughts and ideas. After the nineteenth century, along with some other feminists such as Bertha von Suttner (1843-1914) Emmeline Pankhurst (1858-1928), the British writer, Virgina Woolf with A Room of One's Own (1929), Three Guineas (1938) and the French philosopher and writer, Simon de Beauvoir with The second sex (1949) spread the feminist consciousness all over the world...The feminist activities and struggles for gender equality have been continuously taken place so far and changed the gender awareness in both male and female writers. Many aspects of life including stories about wars have been written in a different way originated from gender perspective.

In Vietnam, after 1975 when the war was over, generations of writers have conditions to look back the struggle of the nation from many aspects. From the view of "feminine disposition". War's dimensions have been reflected in the post-war prose that created its own identity (Ho, 2006). Although praise is not a key inspiration, post-war prose aims to explore the beauty of life and people during and after the war (Nguyen, 2001). However, instead of paying attention to the beauty of groups, individual heroes, writings on the theme of war after 1975 mainly focused on daily life beside the war (the beauty of the companionship, and silent 
sacrifice of unknown soldiers) (Nguyen, 2010). War is attached to devastation, separation and loss; but war is also an environment to challenge human qualities (Nguyen, 2015). From the gender perspective, that is the beauty of women- the "germ of life" surviving in bombs and death. According to Chu Lai- a writer, who used to fight in the war, claims that women are always a place for soldiers to rely on. In many novels, he made up the gentle beauty and femininity of female characters such as youth volunteers, nurses and contact women (Living off the Past, Sun on the Plains, Three Times and One Time ...). Ta Duy Anh wrote about love in the bombing frontline and reflected humanity beauty: "I couldn't understand how hard I cried at the first moment I devoted my life to him. He cried too. At that time, I believed that, once his tears blinded with mine, angels there would appear" (The most beautiful woman of old days). War also brings the pain of desire for love and consecrated virginity (They Have Become Men by Pham Ngoc Tien). War and love, war and instinctive desires have become humanity issue- a general feature of post-war prose.

People inherently do not choose war. They only accept the war and fight when it happens. However, the attitude and reaction of each individual, community and nation toward unexpected wars are not always the same. On the one hand, some are eager to fight in the just war to defend the nation with the ideology of young age. On the other hand, there are also weariness, exhaustion and depression of those who are not strong enough to face the cruel war. There are hopes for the reunion, and also waiting in vain. There are not only heroic glory and victorious smile, but also silent tears in the dark...

From the gender perspective, Vietnamese writers thoroughly explore the pain of women. In the war, not only soldiers walked a thin line between life and death but also women were the ones suffered from "double" loss. For them, war is insecurity, desires, husband waiting and life-lasting obsession of the pain. In "The Sorrow of War" novel, Bao Ninh portrayed the pure beauty of Phuong when she bathed peacefully under the sky of Hanoi despite bombing and violence. But, Phuong, a beautiful, young woman of Hanoi was sexually assaulted in the first days of the war. Also, Bao Ninh mentioned another fact of war by physical and mental pain. This is also a common feature of many writings. War is attached to the sorrow of love. War is attached to women's sacrifice. Thao and other youth volunteers were taken away their youth beauty by bombing and hardship in Truong Son forest (Survivor of the Laughing Forest - Vo Thi Hao). They not only suffered from physical injuries, but also carried the mental pain: the depression illness, complex of being disabled and being abandoned after the war (Returning to Chau River Wharf - Suong Nguyet Minh, The Women on the Island - Ho Anh Thai); the pain of consecration of virginity and prejudices of society (A Wharf with No Husband - Duong Huong, They Have Become Men - Pham Ngoc Tien).

Contemporary war themed Vietnamese fiction particularly pays attention to the pain of women waiting for husband during and after the war. War was over. It seems that there is only happiness of the reunion and peaceful daily life when men come home. But, for many women, they cannot become wife, mother when their husbands are back. Two children of Hanh and Tham in $\boldsymbol{A}$ Wharf with No Husband are the result of forbidden loves. To satisfy the thirst for becoming mother, many women even prostituted themselves or committed incest to produce a child. How can be possible to condemn or judge these women in the name of a moral concept? Putting yourself in the circumstances of women in Dong Village like Hanh and Tham or living in Deo Village where had the only man "a concreted soldier in the Statue of Victory" and widows carved the tombstones in the shape of human body (Mossgreen Wind gust - Vo Thi Hao), that can fully understand the cruelty of the war on women. 
From the gender perspective, many writings thoroughly explore the sexual repression. Many couples were separated by the war and stayed in waiting and missing. During the war, they waited and then they continued to wait after the war. Time made the youthfulness fade away and cruelly passed by while many women still waited (The scent of rice - Duong Huong, The most beautiful woman of old days - Ta Duy Anh, Two Village Women Nguyen Quang Thieu). Some women were lucky to have their husband home and became mother. Unfortunately, the consequences of Agent Orange caused birth defects and baby born with disability. There is not the sound of guns but the stories about war with a long-lasting pain. The pain of Agent Orange is the biggest pain ever of women - soldiers' wives suffered from the war (Thirteen Wharves - Suong Nguyet Minh, The Goat Horn Bell - Nguyen Quang Lap).

\section{Feminist Perpective on the War}

One of the novels which early mentions the right to be a mother of women who came out from the war, or became victim of the war, particularly women who sacrificed their youth in the battlefield is The Women on the Island by Ho Anh Thai. The story is about the fate of thirty-eight women aged from twenty-one to forty-four (one married woman but no children) in Production Brigade Five of a state forestry enterprise. Most of them were veterans sent to work in a remote island with no population and no men (except for two men: one who seemed to lose his male vigor and the other was considered as a woman...). There, hardened by the war and deprived of their chances to marry, these women still dreamed to bear children. According to Ho Anh Thai, one of the reasons to write this novel is that he wants to contribute to "the debate over the rights of unmarried women with children". Claiming for "private happiness" of these women was sadly, painfully uttered by Mien, the leader of Production Brigade Five: "We have peace now, but the men we were waiting for never returned. During the American war we lived at the edge of death, and we were able to control our instinctual desires. But now such control is impossible. I know I lost my opportunity to get married. But if at least I had a child, I would be consoled in many ways. If I hadn't been so concerned with "preserving" myself all those years ago, at least I could have had a child with my beloved. And at least I wouldn't have to suffer like I do now. But he's dead, with all the rest, and who did I keep myself for? What do I need with my virginity, when all it does is bring me loneliness? The collective can help me strengthen my will-power, it can console me a bit. But the collective can't bring me private happiness ".

Telling stories about women who found any men to "produce children" or passed the jungle to meet their lovers that sometimes they have to pay by the death, according to Wayne Karlin: "Ho Anh Thai became one of the first writers in Vietnam to bring attention to what had been a forbidden subject: the terrible cost paid by Vietnamese women who were veterans of the American war" (Karlin, 2001). After The Women on the Island had been published for one year, articles in Marriage \& Family Law was modified, among that women have the right to have illegitimate children. It cannot be sure that the writer made it but it can show the great cognitive function of literature and literature truly cares about women's rights

Since 1975, many female writers in Vietnam have innovated their writing style about war emphasizing women's rights. Feminist consciousness is the development and highest expression of gender consciousness in women. Above self-consciousness about gender, the

typical characteristics of female in relation to male, feminist consciousness is self-awareness 
of the rights and status of women. From these perceptions, female writers ... by many ways, object to prejudices against women in every aspect, including sexual inequality.

Michel Foucault believed that "The third relates to the manner in which the impulse to fashion sexual identities and train one's own body to engage in routines and practices ends up reproducing certain patterns within a given society" (Foucault, 1976). Simon de Beauvoir, a renowned existentialist and feminist was famous for her awareness about sexual equality "To be a complete individual, equal to man, woman has to have access to the male world as man does to the female one, access to the other" (Beauvoir, 2010). Despite writing about war, the subject that less pays attention to individual, sexual desire of human-being, many female writers affirm women's status and sense of sexuality (Beauvoir). In the process to build up the self, story tellers not only confirm the ego but also free themselves by being aware of their beauty, self -consciousness; instinctive desires or sexual experience.

During the war, writers often created stories by the motif "Overcome inner feelings for the great ideology" (Le, 2002). However, since 1975, Vietnamese writers have focused more on the own pain and thirst for happiness in daily life. There were views on writing about war: "Whenever I cannot write a great thing about soldiers, I am still obsessed" (Do Bich Thuy) or "I can stop being obsessed by war in this small country. I have been writing about war from the view of a person grown up after war" (Vo Thi Xuan Ha). Female writers haven't noticed the destruction by the war but emotional pain inside (Ngo, 2016). The tragedy of being wife and mother has drawn attention of writers. The war was revealed through fates of single women who passed the marriageable age, longing for being loved (The virgin wife - Han Nguyet, The youth woman - Da Ngan). It was also revealed through sexual fate of women. The motifs of sexual desire, pain, pleasure of giving birth and meaningless war have been expressed by a proud voice about women's vocation...(Tropical monsoon - Le Minh Khue, The Sparrows Fly Across the Woods - Vo Thi Xuan Ha).

Contemporary Vietnamese prose fiction about war, gender consciousness clearly shows in narrative of the first person, the character: I/women/narrator about her own stories, own gender, world affairs...through feminist perspective. In this aspect, writers often tell stories from the inside view. The character and narrator are homogeneous that are called "I" to tell stories that only "I" know (virginity, becoming a woman, extramarital affairs, denying maternal instinct...). The mysteries of gender have been shared in many writings about war. There are also writings that change the person to tell stories, the narrator $\mathrm{I} / \mathrm{man} /$ or another woman to tell about the fate of women through the war (Thirteen Wharves - Suong Nguyet Minh, The most beautiful woman of old days - Ta Duy Anh). Otherwise, there told stories by using objective narrative - the third person but the limited point of view is different from traditional view and the primary discourse is still feminist discourse, the narrative point of view is the inside point of view of women or heterodiegetic narrator/female writer (An Insignificant Family - Da Ngan, Woman Novel - Ly Lan)...

With these characteristics, narrative voice in many works is often emotional. With gender identity and gender consciousness, female writers often "let out" their subjective ideas, concepts and feelings more than male writers. This, on the one hand, helps female discourse clearly shown in literature; on the other hand sometimes pushes them to the area of "gender in literature", instead of integrating with general contemporary literature written about war in Vietnam.

Women whether somehow participated in or were drawn into the war; whether lived during the war or after that, have carried their own pain. It can be said that with rich humanity in many pages, female writers publicly ask for the right to live with their instinct and sexual 
desires (writings by Vo Thi Hao, Ly Lan, Da Ngan, Vo Thi Xuan Ha...), raise the feminist voice in contemporary Vietnamese prose fiction about war.

\section{CONCLUSIONS AND SUGGESTIONS}

Carrying out a study of Vietnam war prose from the gender perspective is very significant. By innovation of novel thinking and dominance of feminism in writing style, Vietnamese writers have refreshed the way of approach and reflected the reality of war. War writers, at various levels, always hinge on the fate of women. That makes contemporary Vietnamese fiction on the theme of war have a female face and rich humanity. Actually, male Vietnamese writers have put favor to women when identifying war from the view of "feminine disposition". However; only with female's writings, feminist voice resounds in contemporary Vietnamese fictions written about the war. Completely deny male views on women, French feminist writer, philosophers, François Poulain de la Barre (1647-1723) wrote "All that has been written about women by men should be suspect, for the men are at once judge and party to the lawsuit" (Beauvoir, 2010); but female writers in Vietnam belonging to generations after 1975 proved that, thanks to them, Vietnam society has different views about the relationship between women and war. Women in writings about war become more aware of themselves and their gender. From their sexual awakening, in many writings, women's voices have become bold feminist spirit. With the consciousness of writing for themselves/their own gender, feminine writing style and gender stories, have made female prose, including writings about war become discourse of "second sex".

Vietnamese literature about war carries the special characteristics of a nation under almost three decades of grief, loss and heroic victory. Human-being, life and events in prose fiction after 1975 in Vietnam have their own face. But from another point of view, war is sadness and loss; the pain which all nations have been suffered during the war is the same. Gender perspective could not completely express major issues in Vietnamese prose, such as philosophy of human fate in war; the tragedy of destruction and the rule of revival; the human desire for peace and liberty... Nevertheless, for us, gender perspective is the common voice, the closest way to deliver the message of peace.

\section{REFERENCES}

Beauvoir, S. D. 2010. The Second Sex. Translated by Constance Borde and Sheila MalovanyChevallier. New York: Vintage Books.

Foucault, M. 1976. The History of Sexuality. Translated by Robert Hurley. France: Éditions Gallimard .

Ho, T.H. 2006. The Literature of War - The value and creativity has not ended yet. Song Huong Magazine, 205 (3), Retrieved November 26, 2008, from: http://www.tapchisonghuong.com.vn/tap-chi/c125/n1146/Van-hoc-Viet-Nam-ve-de-taichien-tranh-nhung-gia-tri-va-sang-tao-chua-ket-thuc.html.

Karlin, W. 2001. Review of Translation of The Women on the Island (Ho Anh Thai), Introduction to be published by University of Washington Press. The Women on the Island (pp.398). Ho Chi Minh: Youth.

Le, T.H. 2002. Women and war. Cua Viet Magazine, 90 (3), 67-71.

Naish, C. 1991. Death Comes to the Maiden: Sex and Execution, 1431-1933. London: Routledge. 
Ngo, T.Q.N. 2016. A New Concept of Reality of War in Vietnamese Novels after 1975. Retrieved April 14, 2016, from: http://khoaspnv.vinhuni.edu.vn/nghien-cuu-khoahoc/seo/quan-niem-moi-ve-hien-thuc-chien-tranh-trong-tieu-thuyet-viet-nam-sau-197554468.

Nguyen, H.G. 2001. Peace soldiers in war novels in the renovation era. The Army Literature And Art Magazine, 4, 71-75.

Nguyen, T.K.T. 2010. Human-being in post-war novels written about the war. Ho Chi Minh City University of Education - Journal of Science, 23, 19 - 25.

Nguyen, T.T. 2015. Innovative views on war of Vietnamese writers after 1975. Retrieved April 26, 2015, from: http://reds.vn/index.php/nghe-thuat/van-hoc/2715-doi-moi-quanniem-ve-chien-tranh-cua-nha-van-sau-19752.

Suong, N.M. The Literature of War: achievement and new challenge. Retrieved May 5, 2014, from: http://vnca.cand.com.vn/dien-dan-van-nghe-cong-an/Thanh-tuu-va-nhungthach-thuc-moi-331 831/.

Todd, J. 2000. Mary Wollstonecraft: A Revolutionary Life . Great Britain: Weidenfel\& Nicolson.

Wollstonecraft, M. 2009. A Vindication of the Rights of Woman. Ed. Deidre Shauna Lynch. 3rd ed. New York: W. W. Norton and Company. 